\title{
The Role of Higher Education System in Labour Market Regulation of a Labour-Abundant Region
}

\author{
Kilinkarova S. G. ${ }^{1} \&$ Efimova E. V. ${ }^{1}$ \\ ${ }^{1}$ Pyatigorsk State Linguistic University (PSLU), Pyatigorsk \\ Correspondence: Kilinkarova S. G., Pyatigorsk State Linguistic University (PSLU), 9, Kalinin Avenue, \\ Pyatigorsk.
}

Received: October 4, 2014 Accepted: October 12, 2014 Online Published: November 29, 2014

doi:10.5539/ass.v11n1p247 URL: http://dx.doi.org/10.5539/ass.v11n1p247

\begin{abstract}
The analysis of labour market development in the North Caucasian Federal District has showed that there is a rather critical problem of employment for the region, especially among the graduates of higher education institutions. The most significant reasons of low rate of job placement of HEI graduates, to which the arisen imbalance of supply and demand at the labour market can be referred, have been identified in the article. The author comes to a conclusion that the higher education system in the region of NCFD needs optimization which must occur not only by reducing the number of higher education institutions but also by improving the quality of higher education. The author offers a package of measures directed at the elimination of the existing imbalance at the labour market and increase of the rate of job placement of HEI graduates: correction of control rates of admission to higher education institutions in EGTS (enlarged group of training specialities) section, study of the order for specialists training with concrete professional competences at the labour market, carrying out the information activities regarding available vacancies among HEI graduates, development and implementation of programmes of support and adaptation of young specialists of high-demand professions.
\end{abstract}

Keywords: higher professional education (HPE), labour-abundance, employment, labour market, educational level, higher education institution (HEI)

\section{Introduction}

In the conditions of formation of innovative economics the necessity for training of the qualified personnel, capable not only to acquire and use the accumulated theoretical knowledge adequately but also to apply a creative approach to using the gained knowledge in practice increasing its own competitiveness by that at the labour market, increases (Casidy, 2014). The additional source of labourers' competitiveness is the educational level of population. The higher education plays a vital role for development of intellectual human resources necessary for the economic growth and development of the country (Jalaliyoon \& Taherdoost, 2012). However, one of the serious problems of contemporary higher education in Russia is its discrepancy to the requirements of the market. In recent years a large number of graduating specialists, having got education diplomas of different levels but not demanded by the labour market, is observed in Russia (Mingaleva \& Mirskikh, 2012). They fill up lists of the unemployed people or are engaged in the activities which do not correspond to their got education.

The problems of elimination of imbalance at the labour market, of increase of competitiveness and quality of labour force acquire special relevance in the labour-abundant regions to which the North Caucasian Federal District (NCFD) is referred.

Many researches of both Russian and foreign scientists are devoted to the problems of formation of the regional labour markets. The problems of forecasting of the labour market, employment and unemployment are elucidated in works of the Russian researchers: A. N. Ananyev, E. V. Belkin, V. A. Gnevysheva, B. M. Genkin, O. A. Kolesnikova, R. I. Kapelyushnikov, A. G. Korovkin, I. S. Maslova, T. G. Morozova, G. A. Parsadanov, A. V. Pikulkin, I. V. Romanenko, L. S. Chizhova, S. I. Shkurko, etc.

Theoretical and methodological aspects of labour market regulation are presented in works of the foreign scientists: W. Beveridge, J. Keynes, K. Marx, A. Marshall, J. Mill, W. Eucken, A. Okun, J. Strachey, L. Ullman, R. Freeman, F. Hayek, A. Hansen, G. Hodgson, etc. A significant contribution to the development of the theory and practice of management of the regional labour markets was brought by P. Dimon, D. Mortensen, C. 
Pissarides who created a model, explaining behaviour of the labour market with "search problems", when there are vacant workplaces and unemployed people at the same time, who intend to place in a job.

The questions of labour-abundance of the regional labour markets are considered in works of S.B. Ashurov, M.A. Barzayeva, Sh.K. Kutayev, Sh.M. Isaev, A.M. Mamilova, etc. The researches of O. Fedotova, V. Latun, E. Sobotkova, E. Bydanova, etc. are devoted to the problems of integration of graduates of higher education institutions into the labour market. Despite a large number of scientific publications a role of the higher education system in labour market regulation of a labour-abundant region remains poorly studied.

The experience of formation of the regional employment models in the developed foreign countries of the world is represented interesting for overcoming problems of the domestic labour market. The economically developed countries, countries with economies in transition and developing countries around the world anyway face a problem of high unemployment and/or part-time employment and need effective labour market regulation. In response to this new problem the States make changes to their labour legislation, strengthen the national labour market institutes and develop policy of employment and labour market. Thus, for example, regulation of the German labour market is aimed at ensuring continuous employment through the conclusion of tariff agreements at the level of labour unions, consulting support of the population on job search, professional development of personnel and training. However, due to the strictly regulated rules of the German labour market the barriers, interfering competitiveness development, are created. The legislation of the country defines the employment conditions requiring the mandatory membership in labour unions and similar associations for conclusion of an employment agreement.

The Japanese model of the labour market is constructed taking into account the national character (stability, continuity, ability to adapt) and it was admitted in the world as one of the most effective models. It is based on the principle of "lifelong hiring" which assumes employment of a worker after his graduating a higher educational institution up to his obligatory retirement. The sizes of social premiums, remunerations and salaries vary depending on seniority duration.

The American model is characterized by very hard conditions of work. Thus, at decrease in production instead of reduction of number of working hours employees of the enterprises are completely exempted from work. At present the state policy of the USA is directed at prevention of the critical unemployment rate which is caused by lack of the qualified personnel, capable to take workplaces with the average salary level. In this regard the state policy of the USA is concentrated on the support of job placement of candidates, improvement of quality of education, training and retraining of professional personnel. Thus, for example, the legislation of the USA for enterprises, carrying out vocational training of non-competitive categories of the population, provides deductions from profit tax. In case of employment of representatives of these population strata, within two years, an enterprise has the right for a tax discount.

In spite of the fact that each national model of labour market regulation has specific features all of them meet the main international standards established by the ILO in the sphere of employment stimulation. Studying the foreign models of regulation of unemployment and employment of the population has the significant practical value for the domestic market. At the same time, relating to the Russian labour market, using foreign methods of state regulation should be carried out taking into account the specifics of the Russian economy.

\section{Methods}

The cornerstone of studying the labour market is the general methodology reflecting its order of implementation consisting of three stages (figure 1).

Stage 1. Characteristic of conjuncture of the labour market

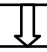

Stage 2. Analysis of characteristics of the labour market

15

Stage 3. Making the forecast of development of the labour market

Figure 1. Stages of carrying out research of the regional labour market 
Within the first stage the leading factors, influencing a condition of the labour market, are identified, the real requirements of the labour market are fixed, the employers' requirements to the specialists and workers' requirements to the working conditions are determined, the balance of manpower of the region is formed.

Collecting the necessary information is carried out by applicating the watching methods. The main forms of statistical watching are the statistical reporting, specially organized watching and registers. The main ways of receiving the statistical information are different types of polls (questionnaire poll, presence poll, expeditionary poll, etc.), direct watching, study of documents. A plenty of factors influences choosing the watching methods, including the purpose of research carrying out, availability of material, financial resources and manpower.

The data of statistical information, of demographic forecast and also the data of territorial offices of the Pension Fund of the Russian Federation, of FMS of the Russian Federation, of Rosstat, of Rostrud, of regional authorities, the results of polling of staff of personnel departments of enterprises situated in the studied region; interviewing of experts of the regional markets serve as an information base for calculation of manpower balance of the region (Gorodetsky \& Danina, 2012).

At the second stage characteristics of the regional labour market are analyzed. The methods of factorial analysis, which provides a number of consecutive operations, is used for it (Akhromova \& Averchenkova, 2008):

1) By the factors, containing requirements of the labour market and included in the manpower balance, the collected information is systematized in databases;

2) The total data on each factor is formulated in tabular and graphic forms.

The labour potential of the region has quantitative and qualitative aspects which must be carefully studied in the process of analysing as subsequently on their bases the forecast of perspective development of the labour market is developed.

The quantitative aspect is expressed in such indicators as the total number of able-bodied population, working hours and use of them, level of population's economic activity, unemployment rate, need of the enterprises and organizations of the region for workers, number of unemployed people, looking for job, etc. The qualitative aspect of the labour potential of the region is expressed in the indicators of a state of health, level of education and professional qualification training of specialists, satisfaction of employers' needs for labour force.

Monitoring of job placement of young specialists - graduates of educational establishments of professional education is of no small importance. To analyse the processes of graduates' job placement and determination of the directions of training, demanded at the market, a number of indicators, allowing not only to estimate an actual state of graduates' job placement but also to specify the factors, having impact on their distribution, is used. To the main indicators of graduates' job placement can be referred: coefficient of intensity of graduates at the labour market, success of placing in a job, relative and absolute indicators of efficiency of job placement, coefficients of prospect and speed. Coefficient of intensity at the labour market $\mathrm{C}_{\text {intens }}$ characterizes a condition of balance between supply and demand at the labour market and is calculated by the formula (Pitukhin \& Serezhina, 2012):

$$
\mathrm{C}_{\text {intens }}=\Delta \mathrm{Pn} / \Delta \mathrm{Qv} . \mathrm{w} \text {. }
$$

$\Delta \mathrm{Pn}$ - extra number of workers arrived at the labour market (including the graduates of educational establishments and migrants looking for work).

$\Delta$ Qv.w. - extra number of vacant workplaces.

The success of a graduate's placing in a job is reflected by the indicator of absolute efficiency of job placement (Androsova, 2013) which represents the total amount of wages received for the time period worked at the first workplace.

The indicator of relative efficiency of job placement reflects the rate of payment for a graduate's work at the first workplace. It is calculated by the formula:

$$
\text { Cre }=\frac{176}{n} \sum_{i=1}^{n} \frac{p}{t}
$$

where 176 - number of hours worked per month at 40-hour working week;

$\mathrm{N}$ - number of graduates, people;

$\mathrm{P}$ - total amount of a graduate's wages for hours worked, rub.

$\mathrm{T}$ - number of hours worked at the first workplace, full months. 
The prospect of graduates' placing in a job by the got speciality is determined by the indicator calculated by the formula:

$$
C_{p j}=\frac{T_{n}}{n}
$$

where $\mathrm{Tn}$ - number of graduates placed in a job by the got specialities, people.

$\mathrm{N}$ - number of graduates

Speed of a graduate's placing in a job by the got speciality (Cs) in the region is determined with the help of the index of average duration of job search by the formula:

$$
C_{s}=\frac{\sum_{1}^{n} t}{n}
$$

$\sum_{1}^{n} t-$ duration of first job search by all graduates, months.

$\mathrm{N}$ - number of graduates

Coefficient of a graduate's fixing at the first workplace

$$
C_{f i x}=\frac{\sum_{1}^{n} T_{r}}{n}
$$

where $\sum_{1}^{n} T_{r}$ - general duration of stay at the first workplace till a graduate's leaving/dismissal

$\mathrm{N}$ - number of graduates

As the basic data for calculating of the above listed indicators are the data being received from the polls of graduates and employers and also the information from the forms of the statistical reporting, the watching control of the developed indicators is reduced to the control over the timely receiving results of polls and forms of the statistical reporting. For each of the indicators setting acceptable region, proceeding from a criterion of suitability of the real indicators of the results of monitoring of graduates' job placement, is supposed (September 10, 2014).

Within the third stage the probable orientation of the regional market development in the economic, scientific-technical, social aspects is defined and also the short-term forecast of the labour market development is made. The method of time-series regression is applied to make the forecast of the regional labour market development. Making the short-term forecast of the labour market can be implemented by the method of moving average of a variable. Deficiency of specialists of a certain direction, the number of young specialists or the working specialists of retirement age, etc. can appear as such a variable.

\section{Main Part}

Table 1. Dynamics of unemployment rate by methodology of the International Labour Organization (ILO) in 2011-2013

\begin{tabular}{ccccccc}
\hline & \multicolumn{2}{c}{2011} & \multicolumn{2}{c}{2012} & \multicolumn{2}{c}{2013} \\
\cline { 2 - 7 } & $\begin{array}{c}\text { number of the } \\
\text { unemployed } \\
\text { people }\end{array}$ & $\begin{array}{c}\text { unemployment } \\
\text { rate }\end{array}$ & $\begin{array}{c}\text { number of the } \\
\text { unemployed } \\
\text { people }\end{array}$ & $\begin{array}{c}\text { unemployment } \\
\text { rate }\end{array}$ & $\begin{array}{c}\text { number of the } \\
\text { unemployed } \\
\text { people }\end{array}$ & $\begin{array}{c}\text { unemployment } \\
\text { rate }\end{array}$ \\
\hline Russian Federation & $\mathbf{5 0 2 0}$ & $\mathbf{6 . 6}$ & $\mathbf{4 1 3 0 . 7}$ & $\mathbf{5 . 5}$ & $\mathbf{4 1 3 7 . 4}$ & $\mathbf{5 . 5}$ \\
NCFD & $\mathbf{6 6 3}$ & $\mathbf{1 5 . 0}$ & $\mathbf{5 8 6 . 8}$ & $\mathbf{1 3 . 1}$ & $\mathbf{5 8 6 . 2}$ & $\mathbf{1 3 . 0}$ \\
Republic of Dagestan & 167 & 12.8 & 155.3 & 11.7 & 152.8 & 11.6 \\
Republic of Ingushetia & 121 & 48.8 & 96.3 & 47.7 & 87.7 & 43.7 \\
Kabardino-Balkar & 43 & 10.8 & 34.1 & 8.9 & 44.2 & 10.5 \\
Republic & & & & & & \\
Karachay- Cherkess & 20 & 9.6 & 21.1 & 8.9 & 22.2 & 9.8 \\
Republic & 30 & 8.4 & 27.8 & 7.9 & 27.8 & 8.1 \\
Republic of North & 199 & 36.7 & 177.9 & 29.8 & 174.7 & 26.9 \\
Ossetia -Alania & 82 & 6.0 & 74.3 & 5.4 & 76.9 & 5.6 \\
Chechen Republic & 19.9 &
\end{tabular}


The North Caucasian Federal District occupies about 1\% of the territory of Russia, it accounts for $6.6 \%$ of population of the country. The number of economically active population by the end of 2013 amounted to 4543.5 thousand people, the level of economic activity reached $66.1 \%$ of the total number of population of NCFD.

There is still a rather critical problem of population employment in the region for many years, the unemployment rate in all subjects of NCFD, except for Stavropol Territory, exceeds the average Russian rate. As of January 1, 2014 the number of the unemployed people of NCFD made 586.2 thousand people, the unemployment rate made $13 \%$ (Inspection of population on employment problems, 2014) (table 1).

The highest unemployment rate in NCFD is noted in the Republic of Ingushetia (43.7\%) and in the Chechen republic (26.9\%). Today NCFD has the highest unemployment rate compared to the other regions of the Russian Federation (figure 2).

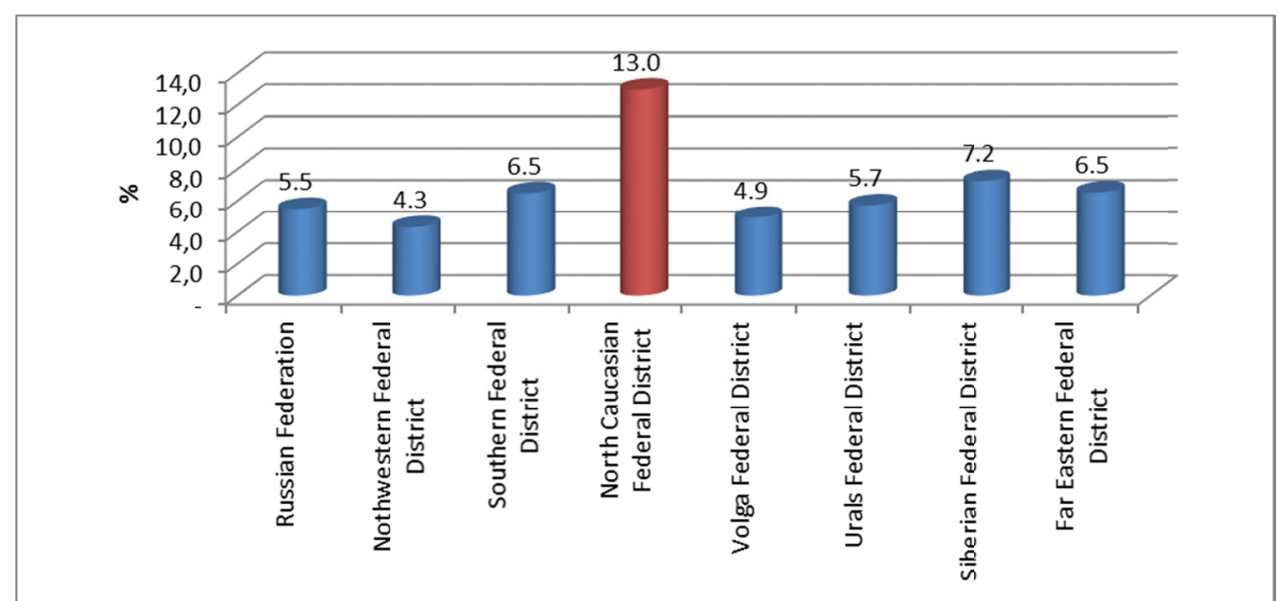

Figure 2. Comparative unemployment rate in the Federal districts of the Russian Federation, \%

There should be noted the positive growth of the indicators of the employment rate of population, which has increased from 55.1\% in 2011 to $57.3 \%$ in 2013. However, this indicator remains below the average Russian rate (64.8\%) throughout the considered period.

On the whole NCFD is referred to the labour-abundant regions as the indicator of the general unemployment rate exceeds $10 \%$ (Kutayev, 2009). The exceptions are only three subjects which are a part of NCFD - the Karachay-Cherkess Republic, the Republic of North Ossetia-Alania and the Stavropol Territory.

To the main reasons for chronic labour-abundance of the region can be referred:

- population density higher than the national average. Thus, the population density of NCFD makes 55.98 people $/ \mathrm{km}^{2}$, the average Russian rate -8.4 people $/ \mathrm{km}^{2}$.

- rates of natural increase. NCFD still provides the greatest absolute rate of population increase among all the Federal districts of the Russian Federation. Thus, in 2013 the natural increase of NCFD population made 9.2 people on 1 thousand inhabitants, the average Russian rate -0.2 people on 1 thousand inhabitants.

- rather high share of youth. The population share in age group of $14-30$ years makes $29.3 \%$ of the total number of inhabitants and exceeds the average Russian rate which is $21.3 \%$ (Demography, 2014).

- prevalence of rural type of settling. The share of the rural population of NCFD makes $50.8 \%$. This is one of the highest rates in the Russian Federation, this rate averages $26 \%$ all over the country. As the most part of workplaces is concentrated in the cities, the most difficult situation with job placement is noted in rural areas where $55.6 \%$ of unemployed citizens live.

Despite some decrease of coefficient of intensity in 2013 NCFD has the highest load rate of unemployed population counting on 100 declared vacancies among all the Federal districts of the Russian Federation (figure 3).

Despite rather high unemployment rate, the need for workers, declared by employers, grows in NCFD. This indicator has increased from 14885 people in 2010 to 24933 people in 2012, i. e. for $67.5 \%$. 


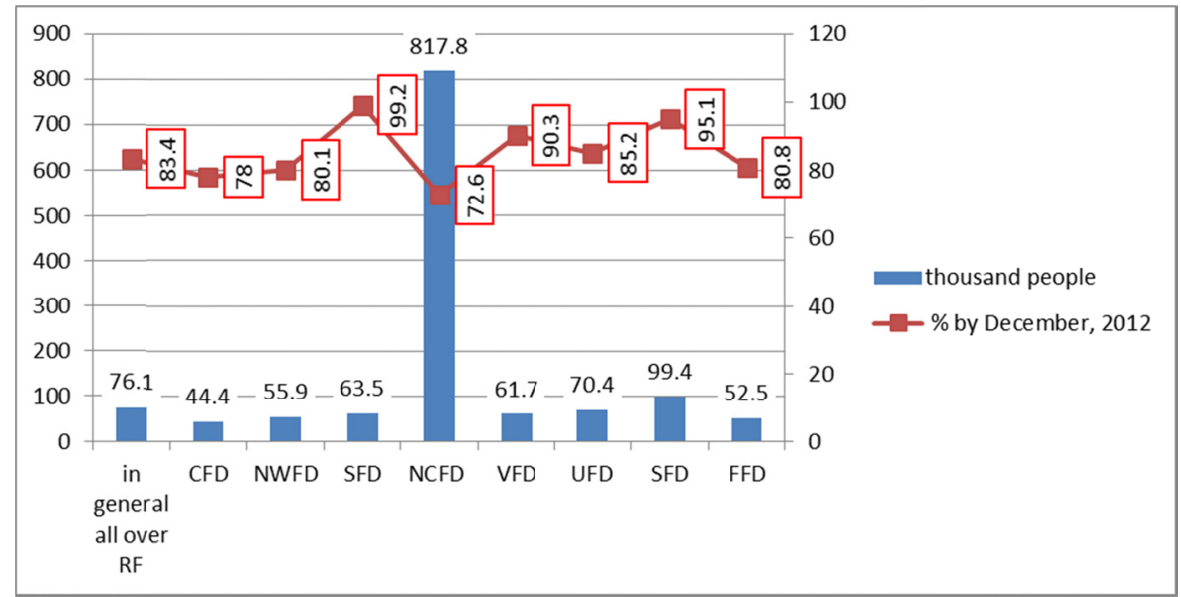

Figure 3. Load of unemployed population, registered in public institutions of employment service of population, on 100 declared vacancies at the end of December, 2013 (Social and economic situation of federal districts, 2013)

The educational level of economically active population in NCFD lags a little behind the similar rate all over the Russian Federation. Thus, $30.1 \%$ of the employed population in NCFD have the higher education, this rate averages $31.7 \%$ all over Russia.

At the same time in a number of the subjects, which are a part of NCFD (The Karachay-Cherkess Republic, the Republic of North Ossetia-Alania, Stavropol Territory), the population share, having the higher education, exceeds the average Russian indicator (figure 4).

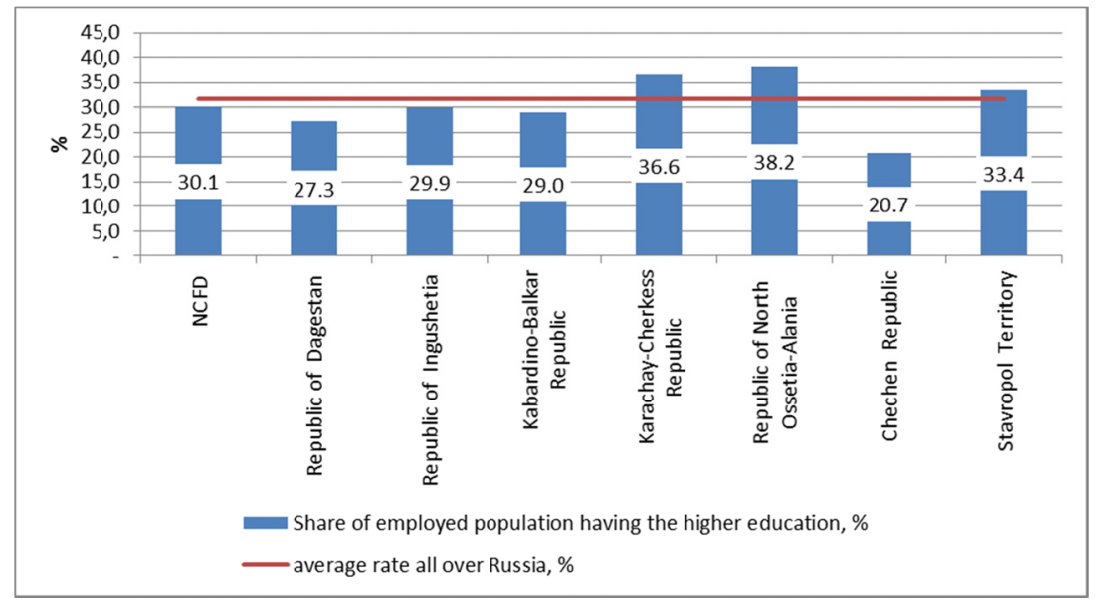

Figure 4. Share of employed population of NCFD with the higher education in 2013

The higher education system of NCFD is presented by 26 state and municipal higher education institutions, 29 private higher education institutions. Besides at the beginning of 2013/2014 academic year there are 108 branches of educational establishments of higher professional education functioning in the district. In 2013/2014 academic year the general contingent of students made 313.2 thousand students (table 2).

In NCFD as well as all over the Russian Federation a trend for further optimization of number of the educational organizations of the higher education remains actual (Klyachko, 2013). Thus, for the last three years the total number of the educational organizations of the higher education decreased by 6 units ( 3 private and 3 state higher education institutions). The number of graduating specialists with the higher professional education has decreased from 74.9 thousand people to 70.4 thousand people for the same period.

As most of the subjects, which are a part of NCFD, belong to the category of labour-abundant and depressive subjects, there are problems of placing in a job of graduates of higher education institutions not only by the educational specialities but even according to the got qualification. 
Table 2. The educational organizations of the higher education of NCFD at the beginning of 2013/2014 academic year

\begin{tabular}{|c|c|c|c|c|c|c|}
\hline & \multirow{2}{*}{$\begin{array}{c}\text { Number of } \\
\text { organizations, total, } \\
\text { unit }\end{array}$} & \multicolumn{2}{|c|}{ Including } & \multirow{2}{*}{$\begin{array}{l}\text { Number of } \\
\text { students, total, } \\
\text { thousand people }\end{array}$} & \multicolumn{2}{|c|}{ Including } \\
\hline & & $\begin{array}{l}\text { State and } \\
\text { municipal }\end{array}$ & Private & & $\begin{array}{c}\text { In state and } \\
\text { municipal }\end{array}$ & $\begin{array}{c}\text { In } \\
\text { private }\end{array}$ \\
\hline Russian Federation & 969 & 578 & 391 & 5646.7 & 4762 & 884.7 \\
\hline $\begin{array}{c}\text { North Caucasian } \\
\text { Federal District }\end{array}$ & 55 & 26 & 29 & 313.2 & 265.5 & 47.8 \\
\hline $\begin{array}{l}\text { Republic of } \\
\text { Dagestan }\end{array}$ & 17 & 6 & 11 & 95.2 & 81.1 & 14.1 \\
\hline $\begin{array}{l}\text { Republic of } \\
\text { Ingushetia }\end{array}$ & 1 & 1 & - & 10.6 & 10.2 & 0.4 \\
\hline $\begin{array}{c}\text { Kabardino-Balkar } \\
\text { Republic }\end{array}$ & 4 & 3 & 1 & 21.3 & 16.7 & 4.6 \\
\hline $\begin{array}{c}\text { Karachay-Cherkess } \\
\text { Republic }\end{array}$ & 2 & 2 & - & 14.8 & 12.7 & 2.1 \\
\hline $\begin{array}{l}\text { Republic of North } \\
\text { Ossetia-Alania }\end{array}$ & 9 & 5 & 4 & 30.2 & 25.8 & 4.4 \\
\hline Chechen Republic & 3 & 3 & - & 31.9 & 31.7 & 0.2 \\
\hline Stavropol Territory & 19 & 6 & 13 & 109.3 & 87.4 & 21.9 \\
\hline
\end{tabular}

The share of unemployed graduates of educational establishment of higher professional education makes about $20 \%$ on all enlarged groups of training specialities and directions (EGSD) all over the North Caucasian Federal District (figure 5).

In NCFD the share of unemployed graduates by the educational specialities 150000 "Metallurgy, mechanical engineering and materials processing", 130000 "Geology, prospect and development of minerals", 050000 "Education and pedagogics" is very high that does not correspond to the all-Russian tendencies.

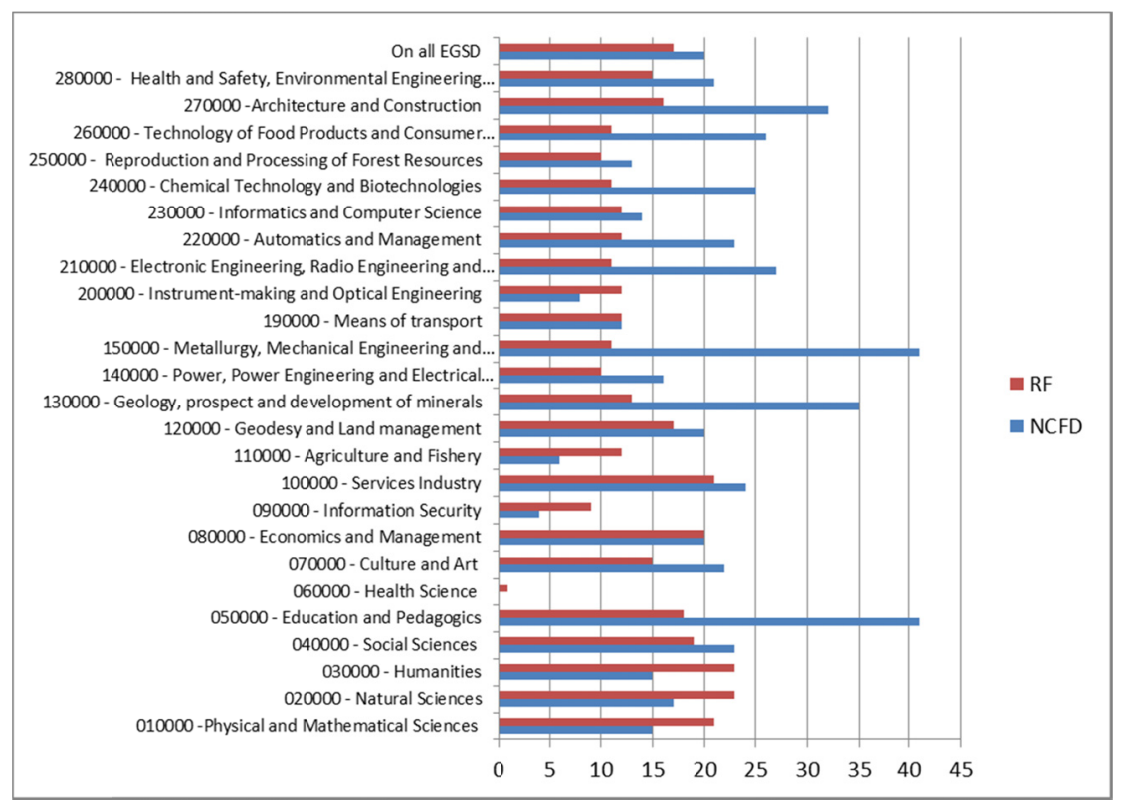

Figure 5. Share of unemployed graduates of educational establishment of higher professional education of the total number of graduates in EGTS section all over the Federal districts and the Russian Federation in general, July, 2012 (September 10, 2014)

The largest percentage of unemployed graduates is in the Chechen Republic and Kabardino-Balkar Republic. The situation of job placement is better and unemployed graduates made less than $5 \%$ in the Republic of North Ossetia - Alania. 
The rate of job placement by the got educational speciality in NCFD is $47 \%$ that corresponds to the average Russian value. The percentage of the employed graduates by the specialities "Instrument-Making and Optical Engineering", "Culture and Art", "Services industry", "Social Sciences", "Agriculture and Fishery" and "Chemical technology and Biotechnologies" exceeds the average Russian rate. At the same time less than $40 \%$ of graduates of EE HPE of the North Caucasian Federal District placed in a job by the educational speciality on EGSD 020000 "Natural Sciences", 150000 "Metallurgy, Mechanical Engineering and Materials Processing", 210000 "Electronic Engineering, Radio Engineering and Connection", 250000 "Reproduction and Processing of Forest Resources".

In general all over NCFD the number of graduates of establishments of higher education covers the general need for specialists with HPE. However, as in general all over the Russian Federation, in North Caucasian FD the most demanded by employers EGSD and most popular with entrants EGSD do not coincide. Especially it should be paid attention to the significant imbalance of these rates on EGSD 080000 "Economics and Management", 030000 "Humanities" and 100000 "Services industry" (The system of interactive monitoring of job placement of graduates.). Thus, according to EGSD data the number of graduating specialists exceeds the existing need in 4.31 times; 3.55 times and 2.09 times accordingly (figure 6).

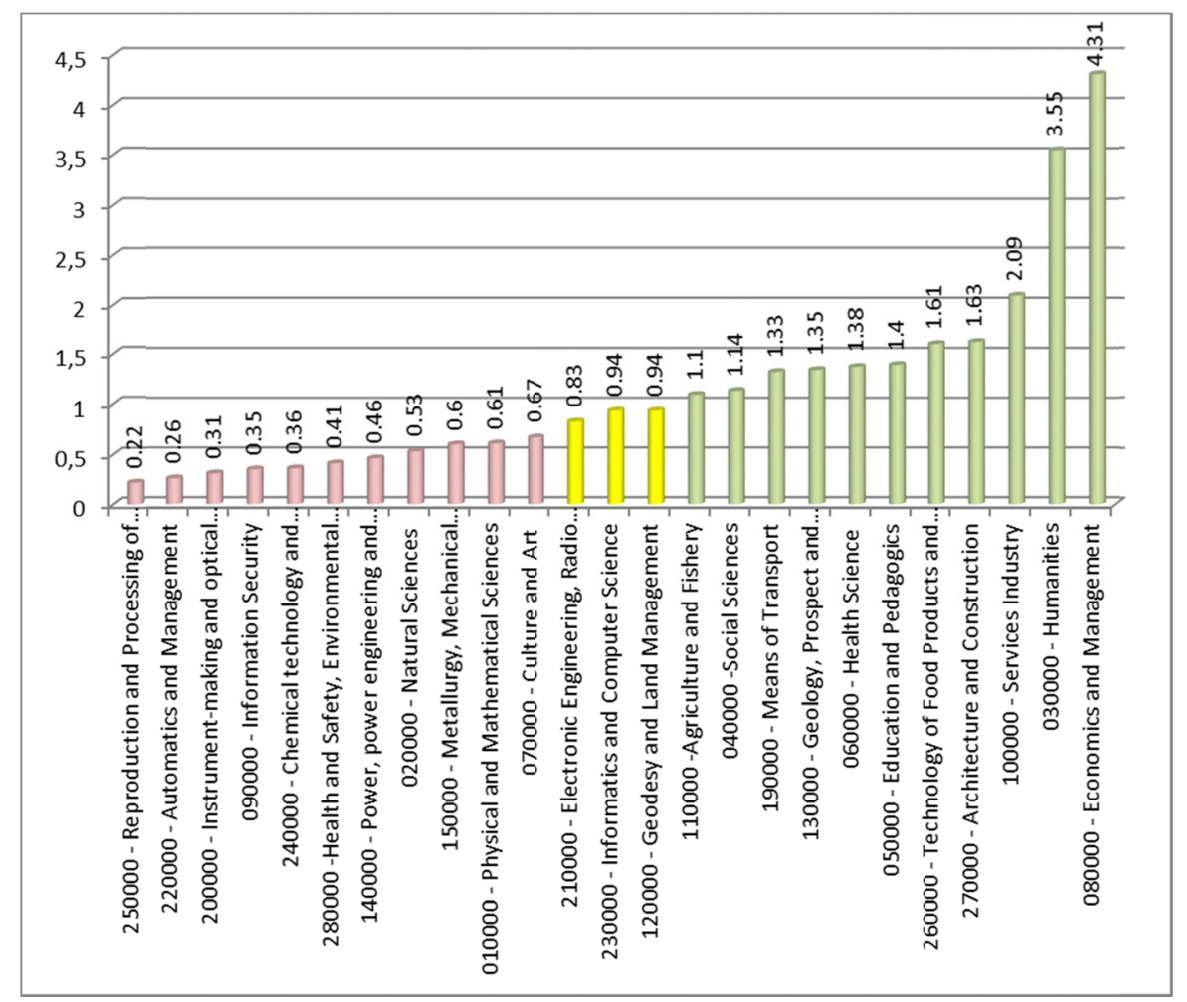

Figure 6. Ratio of the number of graduates, having studied on full-time tuition in EE HPE, and calculated need for specialists with HPE

At the same time deficiency of specialists on EGSD 250000 - "Reproduction and Processing of Forest Resources", 220000 "Automatics and Management", 200000 "Instrument-making and optical engineering", 090000 "Information Security", 240000 "Chemical technology and biotechnologies" is felt.

\section{Discussion}

The problems of labour-abundance in NCFD are in focus of constant attention of scientific and expert community. The main reason for current situation at the labour market is a serious imbalance in training of personnel. The Head of the Federal Service for Supervision in Education and Science S. Kravtsov declared the necessity of changes in the structure of a network of the higher education establishments which must be focused on the demands of economy of NCFD (News and incidents, 2013). Today the considerable part of universities of NCFD continues to admit the first-year students on the budgetary places in the directions related to the 
economics, management and state administration. Thus, insufficient importance is given to those specialities which belong to the priority branches of economic development of NCFD. Meanwhile, NCFD has favourable conditions for development of agro-industrial complex, tourism, sanatorium-resort sphere, electric-power industry.

The same position is shared by the rector of the North Caucasian Federal University A. Ayevitskaya noting that to keep the similar practice means to continue to increase already a large number of unemployed people in the regions of NCFD for the state money (Phioletov, 2013). The correction of policy of higher education institutions of the district on admittance of students according to the demands of today's economy is required. Higher education institutions should conduct this work in cooperation with employers and representatives of profile departments.

At present the problems of development of the labour market and NCFD are quite actively discussed at various levels of government, the special part in the solution of these problems is assigned to the quality of education at that which is a condition for professional development of personnel. Thus, at the next meeting of the Government Commission on the Social and Economic Development of the North Caucasian Federal District of October 2, 2012 D. Medvedev emphasized that "vital prospects, professional realization of young people depend on the quality of education and it is very important for this region. But not to a lesser extent it is a question of preservation of single cultural and spiritual space of the country" (Official portal of the Government of the Russian Federation, 2012).

At the meeting of Council of rectors of higher education institutions of the district, held on November 22, 2013 in Pyatigorsk, the Deputy Prime Minister of the Russian Federation - the plenipotentiary of the Russian President in NCFD A. Khloponin designated the main tasks facing the higher school of the district today. Among the priorities is interaction of higher education institutions with the largest employers of the North Caucasian regions (The Caucasian higher education institutions will learn cooperation with employers, 2013). The Higher education institutions of the district should learn to offer the opportunities to large business more actively and businessmen should change their settled frame of reference to the labour market. One more significant subject is expansion of integration of higher education institutions of the district into a universal educational context. It is important not only to provide students' going out for foreign probations but also to learn to involve the best world teachers to the Caucasus. In particular, it is planned to continue to increase efforts on its improvement, clarification from the inefficient branches of the higher education institutions which have turned into the "factories of diplomas" long ago.

It is indisputable that the higher education system of the region needs optimization. However, reduction of the number of students in HEI cannot be considered as optimal variant of solving a complex social-economic problem of NCFD. It is obvious that optimization of the higher education system must be implemented not only by reduction of the number of the higher education institutions but also, that is more important, due to increase and improvement of quality of the higher education (Antipyev, 2012).

\section{Results}

Improvement of the system of higher professional education in the average and long term consists in the necessity of taking a package of measures directed at the elimination of the negative factors having impact on the low rate of job placement of HEI graduates and considering the requirements of the regional labour market.

The success of the higher school in many respects consists today in activization of substantial interaction of the higher education institutions of NCFD with employers and their associations. The main emphasis in this cooperation must be put on the increase of the level of practice orientation and fundamentality of HEI graduates' training, improvement of educational technologies and programmes according to the requirements of the labour market development in the North Caucasian Federal District and in each of the subjects which are its part.

The effective measures of the regional authorities, exercising management in education, directed at the elimination of the existing imbalance at the labour market and decrease in unemployment rate in the region are:

- Correction of control indicators of admittance of students in EGTS section towards their reduction (in case of excess of the existing requirement of the labour market);

- On the basis of the results of massive polls of employers and analysis of the professional competences of graduates of the higher education institutions, it should be clearly determined what order of the labour market for training of specialists on all EGTS is. In case of revealing discrepancy of the formed competencies of graduates of higher education institutions to the competences demanded by the employers 
it is expedient to consider a question of carrying out correcting of variable part of the educational programmes.

- Carrying out activities for increase of population's awareness of available vacancies: organization of meetings of employers with graduates, timely providing and updating of a list of vacancies for young specialists in each higher education institution, development of social partnership, etc.

- Carrying out additional activities for support and adaptation of young specialists of high-demand professions directed at improvement of the working conditions offered by employers. For example, development and implementation of programmes for granting temporary accommodation for young specialists, the programmes of preferential crediting, granting interest-free loans for purchasing housing, payment "lifting" for the first years of work on graduating from the higher education institution, etc.

\section{Conclusion}

Education is one of the factors defining a worker's competitive position at the labour market. With other things being equal, the high educational level increases "margin of safety" of a specialist's professional knowledge, thereby increases the probability of his placing in a job on graduating from the higher education institution and reduces the risk of losing his workplace.

The fundamental indicators of real efficiency of a higher education institution and quality of graduate's training become orientation of the educational programmes and graduates at the requirements of the labour market, their susceptibility to innovations.

At the present stage the role of the higher education in development of the labour market in NCFD increases due to the necessity of training personnel of new type, capable to show the high level of productivity and efficiency. The accents are displaced towards improvement of the competence-based approach allowing to adapt the higher education system for requirements of the labour market and demands of the real economics of the region.

\section{References}

Casidy, R. (May, 2014). In the role of the assumed market-oriented higher education sector. Australasian marketing magazine, 2(22), 155-163.

Jalaliyoon, N., \& Taherdoost, H. (2012). Performance evaluation of higher education; a necessity. Procedia Social and Behavioral Sciences, 46, 5682-5686. http://dx.doi.org/10.1016/j.sbspro.2012.06.497

Mingaleva, Zh., \& Mirskikh, I. (2012). Globalization in education in Russia. Procedia - Socialand Behavioral Sciences, 47, 1702-1706. http://dx.doi.org/10.1016/j.sbspro.2012.06.886

Gorodetsky, D., \& Danina, N. (2012). Ways of using labour market research. A Handbook for Personnel Management, 5.

Akhromova, S., \& Averchenkova, E. (2008, February 6). Organization of labour market research. Internet Portal of the National Union of Personnel Officers. Retrieved September 10, 2014, from http://www.kadrovik.ru/modules.php?op=modload\&name=News\&file=article\&sid=7431.

Pitukhin, E., \& Serezhina, M. (2012). Efficiency indicators of job placement processes of graduates of establishments of professional education. Supply and demand at the labour market and at the market of educational services in regions of Russia. Collection of Reports on Materials of the Ninth All-Russian Scientific and Practical Internet Conference, October 31 - November 1, Book III. Petrozavodsk: Publishing house PetrGU.

Androsova, E. (2013, February). Efficiency evaluation of job placement of graduates of higher education institutions (gender aspect). Economic Science and Practice. Materials of the II International Scientific Conference. Chita: Publishing house Young scientist.

Complex methods of monitoring of job placement of graduates of educational establishments of professional education. Retrieved September 10, 2014, from http://симт.pф/docs/metodiki/komplex_metodika.pdf.

Inspection of population on employment problems. Federal State Statistics Service of the Russian Federation. Official website of Goskomstat of the Russian Federation. Retrieved September 10, 2014, from http://www. gks.ru/wps/wcm/connect/rosstat_main/rosstat/ru/statistics/publications/catalog/doc_1140097038766

Kutayev, Sh. (2009, December). Competition at the labour market of a labour-abundant region. Magazine "Regional Economy: Theory and Practice", 39(132).

Demography. Federal State Statistics Service of the Russian Federation. Official website of Goskomstat of the Russian Federation. Retrieved September 10, 2014, from http:/www.gks.ru/wps/wcm/connect/rosstat_ 
main/rosstat/ru/statistics/population/demography

Social and economic situation of federal districts - 2013. (2013). Federal State Statistics Service of the Russian Federation. Official website of Goskomstat of the Russian Federation. Retrieved September 10, 2014, from http://www.gks.ru/wps/wcm/connect/rosstat_main/rosstat/ru/statistics/publications/catalog/doc_1140086420 641.

Klyachko, T. (2013). Education in Russia: Main problems and possible decisions. Moscow: Affair of RANEPA.

About the condition of job placement of graduates of establishments of professional education, in-demand specialties, required competences and expected forecasted personnel needs (by results of monitoring carried out in 83 subjects of the Russian Federation). Department of the State policy in the sphere of the higher education of the Ministry of Education and Science of the Russian Federation. Retrieved September 10, 2014, from http://симт.pф/docs/AnalyticReport/AnalyticReport_full.pdf.

The system of interactive monitoring of job placement of graduates. Centre of the budgetary monitoring PetrGU. Retrieved September 10, 2014, from http://симт.pф/Analytics/AnalyticMonitoring.

The head of the Federal Education and Science Supervision Service of the Russian Federation declared that in the North Caucasian Federal District students learn wrong trades. (2013, November 25). News and incidents. Retrieved September 10, 2014, from http://fedpress.ru/news/society/news_society/1385324230-glavarosobrnadzora-rf-zayavil-chto-v-skfo-uchatsya-ne-na-te-professii

Phioletov, S. (2013, December 16). Recipe for the region. Optimization is prescribed to the higher school of the North Caucasus. Search, 49.

A shorthand report on the meeting of Government Commission on the social and economic development of the North Caucasian Federal District. (2012, October 2). Official portal of the Government of the Russian Federation. Retrieved September 9, 2014, from http://government.ru/news/3778\#sel=2:14:Bch,2:24:Wa7.

The Caucasian higher education institutions will learn cooperation with employers. (2013, November). Official website of the Plenipotentiary representative of the President of Russia in NCFD. Retrieved September 10, 2014, from http://www.skfo.gov.ru/news/2013/11/23/43/.

Antipyev, A. (2012). Problems of interaction of higher education institutions and employers at the labour market. Herald of the higher school-Alma mater, 4, 16-20.

\section{Copyrights}

Copyright for this article is retained by the author(s), with first publication rights granted to the journal.

This is an open-access article distributed under the terms and conditions of the Creative Commons Attribution license (http://creativecommons.org/licenses/by/3.0/). 